\title{
EVALUATION OF THREE WHEAT SPECIES COMMONLY USED IN ORGANIC CROPPING SYSTEMS, CONSIDERING SELECTED TECHNOLOGICAL PARAMETERS FOR ETHANOL PRODUCTION
}

\author{
Vasyl Petrenko ${ }^{1}$, Tamila Sheiko ${ }^{1}$, Liudmila Khudolii ${ }^{2}$, Valeria Bondar ${ }^{3}$ \\ ${ }^{1}$ Institute of Food Resources, Ukraine; ${ }^{2}$ Institute of Plant Variety Examination, Ukraine; \\ ${ }^{3}$ National University of Life and Environmental Sciences of Ukraine, Ukraine \\ vasylpetrenko07@gmail.com
}

\begin{abstract}
The study was aimed to determine and compare some technological properties of different wheat species samples (Triticum spelta L.; Triticum dicoccum (Schrank) Schuebl. and coloured-grain wheat (Triticum aestivum L.)) originated from Central Ukraine location. Those species were evaluated and compared in traits related to ethanol production as the grain yield, content of protein, starch, and falling number. The research was based on the field experiment carried out at the Agronomy experimental station of the National University of Life and Environmental Sciences of Ukraine (Kyiv region) during the period 2014-2015. The data were analysed using ANOVA method. The difference of the weather conditions among the experimental years did not have significant influence on the examined parameters. On the other hand, quality parameters significantly depended on the wheat species. The results obtained indicated significant difference between species in the ethanol yield and falling number compared to protein and starch content. The highest ethanol yield was detected in colouredgrain wheat $8.72-8.80 \mathrm{w} / \mathrm{w} \%$ due to the highest starch content $64.4 \%$ in average. At the same time the ability of foaming, which causes negative effect during the fermentation process, was the highest in emmer wheat samples $20.8 \mathrm{ml} \cdot \mathrm{g}^{-1}$. Overall it should be noted that all three examined wheat species had poor technological properties for bread producing in most characteristics; that is why it is necessary to look for other ways of processing these grain.
\end{abstract}

Keywords: wheat, specie, grain, ethanol, parameter.

\section{Introduction}

Globally there is an increasing interest in using the organic farming system and maximizing grain production in low-input scenarios. Old or "neglected" crops are receiving more attention from growers and processors seeking a niche product, while consumers are seeking potential nutritional, sensory and health benefits by eating food from more traditional sources [1]. On the other hand, interest of consumers in natural, unconventional and nutritional foods led to the development of new specialty food products. One of the main resources for it is so-called "ancient wheats". The main wheat species grown in Ukraine under such agriculture systems are spelt, emmer and common soft wheat with coloured grain.

Hulled wheats are often grown in marginal hill and mountain areas in organic farms, where they are considered suitable crops for sustainable farming systems. Despite several defects, such as plant height, low grain yield and low pasta- and bread-making quality, spelt and emmer have been recovered in modern times thanks to their adaptability to poor soils and unfavourable climatic conditions [2].

Consumer interest in spelt grain (Triticum spelta L.) is believed to be due to its rich flavour, described as sweet and nutty, agreeable texture in baked products, and good nutritional profile. The grain may have higher contents of protein and fibre, minerals, $\beta$-carotene and retinol equivalent than common bread wheat. Spelt is used to make a wide range of consumer products; the most popular from them are leavened bread, cookies etc. [3].

Most of Ukrainian spelt production is organic, because the much higher prices paid for the organic product offsets the reduced yield. The reduced yield is a result of three factors: 1) poorly adapted genotypes; 2) the inherently lower-yielding capacity of the organic, low-input system;3) spelt produces hulled grain, which requires additionally processing before flour milling resulting in quite big losses due to chipping and splitting. Commercially-available spelt in Ukraine is presently restricted to a few poorly-adapted genotypes [4]. Evidence for poor adaptation is limited, but it suggests that the grain yield of current genotypes, including the predominant commercial variety Zorya Ukraini is low relative to standard bread wheats. It is well known that wheat under an organic system can yield from 14 to $44 \%$ less then under a high-input system [5]. 
The tetraploid emmer wheat - Triticum dicoccum (Schrank) Schuebl is one of the crops considered suitable for low-input farming system, where modern conventional varieties are not able to develop their yielding potential at a good level. Emmer is one of the hulled wheat species, which has been grown and used as a part of human diet for a very long time. As people are paying more attention to the diversity and good quality of food products, they have become more interested in these wheat species. Emmer wheat landraces have many advantages, which assure them an important role in the interest of farmers and consumers: they are resistant and tolerant to drought, their root system can better absorb nitrogen comparing with common wheat [6].

Unless using hulled wheats, bio-enhanced breeding such as genetic breeding method was used to improve the nutrient value of wheat. Researches show that coloured-grain wheat (Triticum aestivum L.) contains many needed nutrients. Particularly, it is rich in anthocyanins that have many functions such as antioxidant, antibacterial, anticancer and reduction of the incidence of cardiovascular disease [7]. Therefore, coloured-grain wheat becomes more interesting for producers and consumers, especially in organic production.

No less than $75 \%$ of the total volume of the food grade wheat grain is used yearly for processing into flour. Therefore, to obtain alcohol fodder or low-quality grain is often used, which is spoiled as a result of self-heating, sprouted, damaged by frost, insects etc. Concerning the wheat species mentioned above it should be noted that in some cases backing quality of such grain could be so poor that it becomes unsuitable for producing bread, cookies or any other flour-made products. In this situation, the only way to use this grain in food industry is ethanol production [8;9].

Talking about Ukraine it is known, the expenses on the main raw material in the alcohol cost price while processing grain are rather essential (60-65\% of all the expenses). However, under the conditions of the increase of the population purchasing capacity it is the problem of the output of the high quality finished products, which respond to the modern demands concerning all the organoleptic and biochemical indexes that becomes actual for the alcohol branch. The quality of the final productalcohol, which is the initial raw material in the production of liquor-vodka products, is directly connected with the raw material quality; that is why more and more high demands are made to grain. Now, the output of the high-quality alcohol products is possible, first of all, thanks to using the successful results of fundamental and applied researches as concerns the effective processing of different wheat species grain.

It is well-known that the best raw material for the alcohol industry among cereal crops is wheat, especially its high starch varieties because processing of the wheat grain does not cause essential difficulties in the technological process and the yield of alcohol from one ton of such raw material is higher than other cereal crops have. Most of the distilleries especially those which produce products for export prefer to use ethyl alcohol produced from wheat [10-12].

However, very few publications that discus the question of using the grain of the mentioned above wheat species can be found in the literature. This is a question which has vital importance now. The current study was aimed to evaluate the technological properties of selected advanced wheat species to identify their suitability for further processing.

\section{Materials and methods}

Description of the experimental site. Field experiment was carried out in a certified ecological field at the Agronomy experimental station of the National University of Life and Environmental Sciences of Ukraine (Kyiv region) during 2014-2015. The soil of the experimental site is clay loam (Luvic Chernozems, $\mathrm{Cl}$ ) with a humus content of 4.3-4.5\%, $\mathrm{pH}_{\mathrm{KCl}} 6.8-7.0, \mathrm{P}_{2} \mathrm{O}_{5} 176-187 \mathrm{mg} \cdot \mathrm{kg}^{-1}, \mathrm{~K}_{2} \mathrm{O}$ $440-454 \mathrm{mg} \cdot \mathrm{kg}^{-1}$.

In our research, we used the samples of the wheat species from collection of Ukrainian Institute of Plant Variety Examination, particularly the spelt variety Zorya Ukrainy, emmer wheat variety Golikovska and coloured-grain soft wheat variety Chornobrova. All of varieties mentioned above are Ukrainian breeding and are recommended to be cultivated in Forest-Step zone of Ukraine. The wheat preceding crop was clover in both experimental years. Crops were grown under the organic agriculture system. In this system only organic fertilizers $\left(20 \mathrm{tha}^{-1}\right)$ were applied in crop rotation, without any mineral fertilizers and pesticides. In a breakdown, about $17 \mathrm{t} / \mathrm{ha}^{-1}$ of this fertilizing was dunged on 
other cultures in crop rotation and for wheat there were no less than $7 \mathrm{t} \cdot \mathrm{ha}^{-1}$ stubbly remains (like clover or corn residues). By the wheat cultivation there was only seed processing by a biological fertilizer before sowing (Azofit). Exclusively, mechanical and biological measures were used against weeds.

Description of the weather conditions was based on the data from the meteorological site of the Agronomy experimental station. April and May of 2014 were rather secured by rainfall and had higher temperatures compared to average multiannual data (Figure 1). As a result, sprouting and growth of wheat species were intensive. But after the third decade of May rainfall became rare during all the summer. Due to the lack of water crop formation was faster than usual.

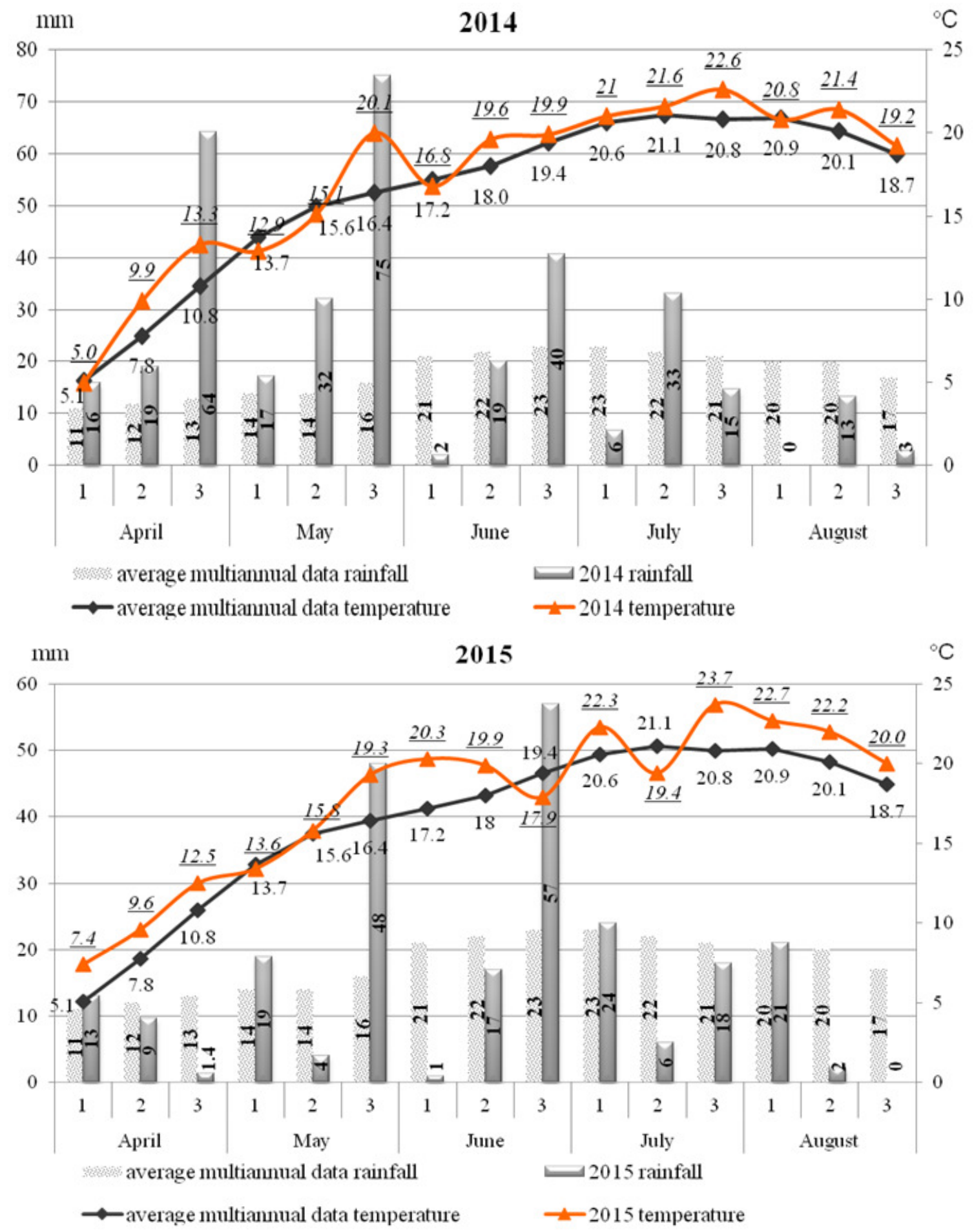

Fig. 1. Rainfall and temperature distribution during growing seasons 
Looking at the 2015 data it is necessary to notice that the average decade temperature was higher than multiannual rate, except the third decade of June and the second decade of July; in conjunction with sporadic rains it was the reason of plant development under drought and very stressful conditions (Figure 1).

Estimation of biochemical properties of wheat species grain was done in grain-milling laboratory of the Institute of Food Resources NAAS Ukraine. The starch content was measured by the standard Ewers`s polarimetric method (DSTU 11212-4:2004, ISO 10520:1997). Concerning other analysis, we determined the physical and biochemical characteristics of grain by the following methods: moisture (ISO 712-6540), raw protein content (ISO 20483) and falling number by the Perten method (ISO 3093). The laboratory ethanol producing method consists of the following steps: prepared in advance starch suspensions (20\%) were fermented by separated hydrolysis and fermentation. The next commercial enzyme products Termamyl®SC (termostable $\alpha$-amylase), Promozyme ${ }^{\circledR D}$ (thermostable pullulanase), and AMG 300L (glucoamylase) (produced by Novozymes, Denmark) in concentration $0.3,0.8$, and $0.8 \mathrm{ml} \mathrm{kg}$ of starch and the Ukrainian strain ВП-14/91 of Saccharomyces cerevisiae were used for starch hydrolysis and fermentation.

The significance of the experimental data was estimated by the analysis of variance (two-factor ANOVA) by evaluating the standard deviation and the least significant difference LSD05.

\section{Results and discussion}

Analysis of variance revealed the influence of wheat species to some technological parameters associated with the ethanol production as the falling number (amylase activity), starch and protein content.

The experimental data show the wide range of starch content in the samples between 49-65\% per dry matter (Table 1). Thus, the researched samples are suitable for processing on alcohol. Comparative analyses of the starch content showed that the lowest value of this parameter was attained by emmer wheat. However, this qualitative parameter was significantly different only for T. aestivum (coloured) in comparison to other estimated wheat species.

Estimation of suitability of wheat grain for any kind of processing is based on determination of its technological value, which usually depends on the concentration of the total protein content. Compared to soft wheat, emmer and spelt have significantly more total protein. Protein level was significantly influenced by the wheat species. The overall measurement results are summarized in Table 1.

The falling number is an indicator demonstrating the amylolitic activity of the grain that significantly influences on the starch degradation, which has vital importance for ethanol producing. The data obtained in our study show that the mentioned index varied mostly significantly among species, being significantly the highest in emmer wheat (showing extremely low ferment activity), while for spelt and T. aestivum (coloured) it ranged from 287 to 322 seconds.

Table 1

Quality indexes of studied wheat species

\begin{tabular}{|l|c|c|c|c|c|c|c|c|c|}
\hline \multirow{2}{*}{ Specie } & \multicolumn{3}{|c|}{ Starch content, \% } & \multicolumn{3}{c|}{ Protein content, \% } & \multicolumn{3}{c|}{ Falling number, sec } \\
\cline { 2 - 10 } & 2014 & 2015 & $\begin{array}{c}\text { Ave- } \\
\text { rage }\end{array}$ & 2014 & 2015 & Average & 2014 & 2015 & $\begin{array}{c}\text { Ave- } \\
\text { rage }\end{array}$ \\
\hline T. spelta & 52.5 & 51.4 & 52.0 & 18.9 & 18.5 & 18.7 & 287.0 & 303.0 & 295.0 \\
\hline T. dicoccum & 50.6 & 49.0 & 49.8 & 20.9 & 20.8 & 20.8 & 466.3 & 427.7 & 447.0 \\
\hline $\begin{array}{l}\text { T. aestivum } \\
\text { (coloured) }\end{array}$ & 63.9 & 64.9 & 64.4 & 13.0 & 13.2 & 13.1 & 322.7 & 309.3 & 316.0 \\
\hline LSD $_{0,05}$ & 3.57 & 2.63 & 4.62 & 0.92 & 0.58 & 0.57 & 15.11 & 22.4 & 14.01 \\
\hline
\end{tabular}

One of the important characteristics of grain for the alcohol industry is the ability of foaming. The high content of protein substances in grain causes the formation an excelling foam amount. It was 
observed during the processing of the grain obtained by the ecological and intensive systems of agriculture (Table 2).

Concerning the analysed parameters higher starch content predicted higher potential for ethanol production. The coloured grain was the best in the starch content, so the examined parameters as the ability of foaming, fermentation degree and ethanol yield were significantly higher than emmer and spelt had.

Table 2

Ethanol yield from wheat species grown in organic agriculture system

\begin{tabular}{|l|c|c|c|c|c|c|c|c|c|}
\hline \multirow{2}{*}{ Specie } & \multicolumn{2}{|c|}{ Ability of foaming, $\mathbf{~ m l . g ~}$} & \multicolumn{2}{c|}{ Fermentation degree, \% } & \multicolumn{3}{c|}{ Ethanol yield, w/w \% } \\
\cline { 2 - 11 } & 2014 & 2015 & $\begin{array}{c}\text { Ave- } \\
\text { rage }\end{array}$ & 2014 & 2015 & Average & 2014 & 2015 & $\begin{array}{c}\text { Ave- } \\
\text { rage }\end{array}$ \\
\hline T. spelta & 11.5 & 10.5 & 11.0 & 93.4 & 93.2 & 18.7 & 7.33 & 7.20 & 7.26 \\
\hline T. dicoccum & 12.0 & 12.0 & 12.0 & 92.9 & 92.8 & 20.8 & 6.39 & 6.14 & 6.27 \\
\hline $\begin{array}{l}\text { T. aestivum } \\
\text { coloured) }\end{array}$ & 8.5 & 8.0 & 8.3 & 95.0 & 95.4 & 13.1 & 8.72 & 8.80 & 8.76 \\
\hline LSD $_{0,05}$ & 0.59 & 0.61 & 0.68 & 0.92 & 0.58 & 0.57 & 0.96 & 0.40 & 1.02 \\
\hline
\end{tabular}

This experiment was conducted up to $2 \mathrm{~h}$, reaction time necessary for complete hydrolysis of starch, when Termamyl ${ }^{\circledR} S C$ and Promozyme ${ }^{\circledR D}$ in a temperature of $75^{\circ} \mathrm{C}$ were used for liquefaction. Liquefaction was necessary for complete starch hydrolysis using raw wheat flour as substrate. The resulting material was used as a substrate in test fermentations in shake flask cultures using yeast strain ВП-14/91 as the fermentation yeast. Samples were taken and the sugar and ethanol concentrations were monitored. Fermentations were run until a plateau concentration of ethanol had been reached, which usually occurred within 30 hours of the start of fermentation.

As the table above shows, it is the brewer's mash from the wheat coloured grain that had the highest concentration of ethyl alcohol and ethanol yield as a result. It can be explained by the higher starch content just in this grain sample. According to the ethanol yield the difference in comparison with the two other treatments of the experiment was about 1.3-2.6\%.

\section{Conclusions}

1. There were significant differences between wheat species in biochemical parameters related to efficiency of ethanol fermentation from grain. Starch content varied from 49 up to $65 \%$, protein content from 13.1 up to $20.9 \%$ and the falling number from 309 up to $466 \mathrm{sec}$. These parameters affected the ethanol yield measured in our research, nevertheless T.aestivum L. with coloured grain generated the highest amount of ethanol during both experimental years.

2. The results obtained show that weather conditions do not have a significant influence on the parameters test instead of wheat specie, which affected all the parameters relevant to such kind of grain processing. At long last variety Chornobrova of T.aestivum L. with coloured grain could be considered as favourable for ethanol production among other wheat species used in organic agriculture.

\section{References}

[1] Trckova M., Raimanova I., Stehno Z. Differences among Triticum monococcum, T. dicoccum and Triticum spelta in rate of nitrate uptake. Czech Journal of Genetics and Plant Breeding, vol. 41, 2005, pp. 322-346.

[2] Hajnalová M., Dreslerová D. Ethnobotany of einkorn and emmer in Romania and Slovakia: towards interpretation of archaeological evidence. Pamyatky Archeolologicke, vol. 101, 2010, pp. 169-202.

[3] Capouchova I. Technological quality of spelt (Triticum spelta L.) from ecological growing system. Scientia Agriculturae Bochemica, vol. 32, 2001, pp. 307-322. 
[4] Morgun V., Sichkar S., Pochinok V., Golik O., Chugunkova T. Analysis of structure performance of rare wheat species collection. Faktori eksperimental'noi evolucii organizmiv, vol. 16, 2015, pp. 136-139.

[5] Escarnot E., Jacquemin J., Agneessens R., Paquot M. Comparative study of the content and profiles of macronutrients in spelt and wheat, a review. Biotechnology, Agronomy, Society and Environment, vol. 16, 2012, pp. 243-256.

[6] Konvalina P., Capouchova I., Stehno Z., Moudry J. Agronomic characteristics of the spring forms of the wheat landraces (einkorn, emmer, spelt and intermediate bread wheat) grown in organic farming. Journal of Agrobiology, vol. 27, 2010, pp. 9-17.

[7] Knievel D., Abdel-Aal E.S., Rabalski I., Nakamura T., Hucl P. Grain color development and the inheritance of high anthocyanin blue aleurone and purple pericarp in spring wheat (Triticum aestivum L.). Journal of Cereal Science, vol. 50, 2009, pp. 113-120.

[8] Petrenko V., Liubich V., Bondar V. Baking quality of wheat grain as influenced by agriculture systems, weather and storing conditions. Romanian Agricultural Research, vol. 34, 2017, pp. 69-76.

[9] Sedláček T. Impact of environmental factors to wheat ethanol production in the conditions of Central Europe. Cereal Research Communications, vol. 39, 2010, pp. 120-129.

[10]Loyce C., Rellier J.P., Meynard J.M. Management planning for winter wheat with multiple objectives: ethanol-wheat production. Agricultural Systems, vol. 72, 2002, pp. 33-57.

[11]Mikulíková D., Horváthová V., Rückschloss L., Gavurníková S., Žofajová A., Kraic J. Differences between wheat cultivars in grain parameters related to ethanol production. Poljoprivreda, vol. 17, 2011, pp. 3-7.

[12] Swanston J.S., Smith P.L., Gillespie T.L., Brosnan J.M., Bringhurst T.A., Agu R.C. Associations between grain characteristics and alcohol yield among soft wheat varieties. Journal of the Science in Food and Agriculture, vol. 87, 2007, pp. 676-683. 